\title{
Occurrence of adulterants and preservatives in the Milk Sold in Rural areas of Omdurman, Sudan
}

\author{
Asged, A. A. Mohammed, I. E. M. El Zubeir \\ Department of Dairy Production, Faculty of Animal Production, University of Khartoum, Khartoum \\ North, Sudan \\ Ibtisamelzubeir17@gmail.com, Ibtisam.elzubeir@uofk.edu
}


Available online at www.refaad.com

VMPH 2(3); 2021: 64-72

Research Article

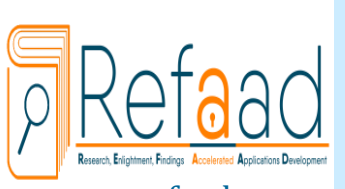

www.refaad.com
Veterinary Medicine and Public Health Journal (VMPH)

Journal Homepage: https://www.refaad.com/views/vmph/home.aspx

ISSN : 2707-7195(Online) 2707-7187(Print)

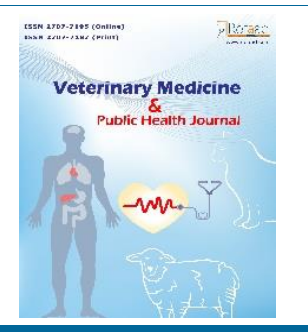

\section{Occurrence of adulterants and preservatives in the Milk Sold in Rural areas of Omdurman, Sudan}

\section{Asged, A. A. Mohammeda, I. E. M. El Zubeir ${ }^{* a}$}

a Department of Dairy Production, Faculty of Animal Production, University of Khartoum, Khartoum North, Sudan

* Corresponding author: I. E. M. El Zubeir. Email: Ibtisamelzubeir17@gmail.com, Ibtisam.elzubeir@uofk.edu

How to cite this article: Mohammed, A.A.A., I. E. M. El Zubeir, Occurrence of adulterants and preservatives in the Milk Sold in Rural areas of Omdurman, Sudan. Veterinary Medicine and Public Health Journal 2(3); 2021: 64-72.

DOI: https://doi.org/10.31559/vmph2021.2.3.1 Received Date: 13/4/2021 Revised Date: 2/9/2021 Accepted Date: 29/9/2021

\section{Abstract}

In the present investigation, the chemical composition of milk was determined and the detection of the presence of some additives and preservatives in raw cow milk obtained from rural area of Omdurman city Sudan was done. The milk samples $(n=120)$ were obtained from rural areas of North and South Omdurman. Significantly, $(P \leq 0.05)$ higher values for the chemical constituents of the examined raw milk samples were reported in the samples from South Omdurman compared to those from North Omdurman. In addition, the results showed that the added water was found in $16.7 \%$ of the examined milk samples. Also, formaldehyde was used as a preservative in $19.2 \%$ of the samples, while boric acid was used as preservative in $25 \%$ of the milk samples in South Omdurman. However, sodium bicarbonate, hydrogen peroxide and starch were not detected. It was concluded that milk distributed in North and South Omdurman contains some adulterants. Hence control and monitoring programs should be directed towards the hygienic quality of milk during production and marketing.

Keywords: Milk adulteration; chemical composition; additives; preservatives. 


\section{Introduction}

Milk is a complete diet due to its carbohydrates, protein, fat, vitamins, minerals and other miscellaneous constituents that dispersed in water in a complex mixture (Haug et al. 2007). Milk is likely to be subjected to spoiling during the hot season due to its perishable e content (Tipu et al. 2007).

Milk adulteration was defined by FDA (2009) as "the fraudulent, intentional substitution or addition of a substance in a product for the purpose of increasing the apparent value of the product or reducing the cost of its production". Currently fraud is of potential food safety and public health concern (Spink and Moyer 2011; Singh and Gandhi 2015; Chauhan et al. 2019; Lahankar et al. 2019). Worldwide milk was among the main defrauded foods during 1980 to 2010 (Moore et al. 2012). Some middle men are found to adulterate the milk in traditional milk distribution system in order to increase the profit where a gap between the demands and supply exist (Lateef et al. 2009).

Adulteration of milk with the addition of variable amount of water, the simplest and oldest forms of milk fraud, will artificially increase its volume and substantially reduced its nutritional value. Moreover, a human health risk can occur due to the potential water borne diseases (Kandpal et al. 2012). Starch, cereal flours or arrowroot are added to make up the density of milk to prevent detection of added water (Jivraj and Astha 2015).

Under tropical and subtropical conditions of the developing countries; where refrigeration is not practical; addition of chemical preservatives including hydrogen peroxide $\left(\mathrm{H}_{2} \mathrm{O}_{2}\right)$ or alkaline solutions for activation of natural antibacterial enzymes are common practices (Ozer et al. 2000). The formalin, which is carcinogenic, is used for preservation and increasing the shelf life of milk although it decreases its nutritive value (Bhatti 2010).

Chemical additives such as sodium carbonate and bicarbonate were added as neutralizers for preservation of milk for longer time and to prevent its curdling (Ahmad et al. 2015). FAO/WHO expert committee declared that boric acid is unsafe and should not be added to the food due to its cumulative toxicity effect (Yiu et al. 2008).

Little effort was done to evaluate and monitor the quality of the market milk, especially in Africa (El Zubeir et al. 2008). Moreover, most of raw milk is sold raw without any heat treatment to the consumers in Sudan (Elmagli and El Zubeir 2006b; Salman and Hamad 2011). According to the previous reports, the distribution and transportation of milk in Sudan are traditional and primitive, which help in increasing the growth and multiplication of bacteria (Elmagli and El Zubeir 2006a; Mohamed and El Zubeir 2007a; El Zubeir and El Owni 2009; Salman and Hamad, 2011; Warsama et al. 2017). Hence proper quality control measures (Mohamed and El Zubeir (2007a) and risk assessment (Addoma et al.
2016) are of a high priority. The aim of this study was determining the compositional content of milk that is offered for sale in the rural areas of Omdurman city. It is also meant to investigate the presence of some contaminants (additives and preservatives) commonly used in the study area.

\section{Materials and Methods}

The area of study:

Two rural areas at Omdurman (North and South), Khartoum State, Sudan were selected for the collection of milk samples. This study was started on 19 December 2016 and ended on 31 January 2017.

\section{Sources of milk samples:}

The raw milk samples used in this study were collected from local vendors in North and South rural areas of Omdurman city, which are distributed widely in the state. About 120 milk samples were collected, 60 milk samples were transported by cars and 60 milk samples were transported by donkeys.

The samples were collected into cleaned and sanitized vials. Some of the samples were collected in the morning and the others were collected during the evening. All the samples were transported in containers containing ice to the dairy chemistry laboratory of the Faculty of Animal Production, University of Khartoum, for analysis. The analysis included the chemical composition of the milk samples and detection for the presence of some additives and preservative substances (water, starch, hydrogen peroxide, boric acid, formaldehyde, and sodium bicarbonate). All the tests were examined at room temperature.

\section{Analysis of milk composition:}

The solids not fat, fat, protein, and lactose were the major chemical component examined in the milk samples using Lactoscan milk analyzer (Milkotronic LTD, Bulgaria). The total solids contents were obtained by the sum of the solids not fat and fat. The gravimetric method using muffle furnace was followed for measuring the ash content (AOAC, 2003).

\section{Tests for detection of additives and chemical preservatives, neutralizers:}

Added water was detected using milk Lactoscan analyzer (Milkotronic LTD, Bulgaria). Detection of starch was done using the method described by Kumar et al. (1998). Detection for the occurrence of formaldehyde, sodium bicarbonate, hydrogen peroxide and boric acid were obtained following the methods describe by Singh et al. (2012); Kamthania et al (2014).

\section{Statistical analysis:}

The generated data about the milk composition were analyzed using SPSS version 11.5 packages (2002). Two-way ANOVA was performed using the 
complete randomize design. When significant treatment effects were noted, the least significant difference at $\mathrm{P} \leq 0.05$ was used to separate the means between the treatments. However, frequencies and percentage were preformed to evaluate the adulteration of milk by venders and regions.

\section{Results and discussion}

\section{Compositional content of milk samples:}

Significant $(\mathrm{P} \leq 0.05) \quad$ differences were estimated for the values of fat for the milk samples collected from rural areas at South and North Omdurman city (Table 1).

Table (1): Comparative analysis of compositional content of raw milk sampled from Omdurman transported by cars and donkeys

\begin{tabular}{|c|c|c|c|c|c|}
\hline Parameters (\%) & Regions & Cars & Donkeys & Maximum & Minimum \\
\hline \multirow[t]{3}{*}{ Fat } & South - & $5.14 \pm 0.62$ & $5.46 \pm 0.83$ & \multirow{3}{*}{$8.35 \%$} & \multirow{3}{*}{$3.41 \%$} \\
\hline & Omdurman & & & & \\
\hline & $\begin{array}{l}\text { North - } \\
\text { Omdurman }\end{array}$ & $4.97 \pm 0.8$ & $5.15 \pm 0.42$ & & \\
\hline \multirow[t]{3}{*}{ Protein } & South - & $3.53 \pm 0.26$ & $3.64 \pm 0.38$ & \multirow{3}{*}{$5.29 \%$} & \multirow{3}{*}{$2.67 \%$} \\
\hline & Omdurman & & & & \\
\hline & $\begin{array}{l}\text { North - } \\
\text { Omdurman }\end{array}$ & $3.48 \pm 0.3$ & $3.45 \pm 0.18$ & & \\
\hline \multirow[t]{3}{*}{ Lactose } & South - & $4.77 \pm 0.31$ & $4.93 \pm 0.52$ & \multirow{3}{*}{$7.09 \%$} & \multirow{3}{*}{$3.07 \%$} \\
\hline & Omdurman & & & & \\
\hline & $\begin{array}{l}\text { North - } \\
\text { Omdurman }\end{array}$ & $4.68 \pm 0.46$ & $4.67 \pm 0.25$ & & \\
\hline \multirow[t]{3}{*}{ Total solids } & South - & $14.1 \pm 1.1$ & $14.79 \pm 0.8$ & \multirow{3}{*}{$15.2 \%$} & \multirow{3}{*}{$8.2 \%$} \\
\hline & Omdurman & & & & \\
\hline & $\begin{array}{l}\text { North - } \\
\text { Omdurman }\end{array}$ & $13.6 \pm 1.4$ & $13.9 \pm 0.8$ & & \\
\hline \multirow[t]{3}{*}{ Ash } & South - & $0.67 \pm 0.075$ & $0.66 \pm 0.063$ & \multirow{3}{*}{$0.79 \%$} & \multirow{3}{*}{$0.28 \%$} \\
\hline & Omdurman & & & & \\
\hline & $\begin{array}{l}\text { North - } \\
\text { Omdurman }\end{array}$ & $0.63 \pm 0.1$ & $0.68 \pm 0.06$ & & \\
\hline
\end{tabular}

Table (2): The average compositional content of milk collected from North and South of Omdurman

\begin{tabular}{llllll}
\hline Regions & $\begin{array}{l}\text { South } \\
\text { Omdurman }\end{array}$ & $\begin{array}{l}\text { North } \\
\text { Omdurman }\end{array}$ & Total & S E & L S \\
\hline Fat (\%) & $5.3 \pm 0.75$ & $4.79 \pm 0.66$ & $5.14 \pm 0.72$ & 0.063 & $* *$ \\
Protein (\%) & $3.59 \pm 0.33$ & $3.47 \pm 0.25$ & $3.53 \pm 0.30$ & 0.027 & $*$ \\
& $4.85 \pm 0.43$ & $4.69 \pm 0.36$ & $4.76 \pm 0.4$ & 0.037 & $*$ \\
Lactose (\%) & $14.4 \pm 1.4$ & $13.75 \pm 1.2$ & $14.1 \pm 1.3$ & 0.116 & $*$ \\
Total solids (\%) & $0.67 \pm 0.07$ & $0.66 \pm 0.09$ & $0.66 \pm 0.79$ & 0.07 & NS \\
Ash (\%) & & & & & \\
\hline
\end{tabular}

$\mathrm{SE}=$ Stander Error for mean

$\mathrm{LS}=$ level of significant

NS= No significant

$*=\mathrm{P} \leq 0.05$

$* *=\mathrm{P} \leq 0.01$

Moreover, the average of fat level (Table 2) in the milk from South Omdurman was significantly $(\mathrm{P} \leq 0.05)$ higher than the milk collected from Northern Omdurman $(5.3 \pm 0.75 \%$ and $4.79 \pm 0.66 \%$, respectively).
However, among the vender's milk samples, the fat content of milk transported by cars $(4.97 \pm 0.74 \%)$ was lower compared to milk samples obtained from vendors using donkeys (5.3 $\pm 0.68 \%)$. The differences among them showed significant differences (Table 3).

Table (3): Variation of the chemical composition of milk between different vendors in North and South Omdurman

\begin{tabular}{lccccc}
\hline Venders & Cars & Donkeys & Total & S E & L S \\
\hline Fat (\%) & $4.97 \pm 0.74$ & $5.3 \pm 0.68$ & $5.14 \pm 0.72$ & 0.063 & \\
Protein (\%) & $3.51 \pm 0.28$ & $3.55 \pm 0.31$ & $3.52 \pm 0.29$ & 0.027 & NS \\
Lactose (\%) & $4.73 \pm 0.39$ & $4.8 \pm 0.42$ & $4.76 \pm 0.4$ & 0.037 & NS \\
Total solids (\%) & $13.85 \pm 1.3$ & $14.35 \pm 1.32$ & $14.1 \pm 1.3$ & 0.116 & $*$ \\
Ash (\%) & $0.67 \pm 0.091$ & $0.68 \pm 0.061$ & $0.66 \pm .079$ & 0.07 & NS \\
\hline
\end{tabular}

$\mathrm{SE}=$ Stander Error for mean

$\mathrm{SL}=$ level of significant

$\mathrm{NS}=$ No significant

$*=\mathrm{P} \leq 0.05$

$* *=\mathrm{P} \leq 0.01$ 
Similarly, Elsheikh et al. (2015) reported higher $(5.08 \pm 0.64 \%)$ fat content in milk transported by pick-up trucks compared to milk from venders on donkey carts $(4.74 \pm 0.66 \%)$. This might be because the venders using cars and trucks brought the milk from far away in addition to the fact that most of them are middlemen while those using donkeys cart transport the milk from nearby farms directly to the consumers. Relatively higher values were obtained in the present results (Table 1 and 2) compared to Mohamed and El Zubeir (2007b), they found $3.75 \pm 1.07$ and $3.46 \pm 1.17 \%$ for the means of fat content of milk sold in Omdurman and Khartoum North, respectively. However, Ahmed and El Zubier (2007) reported that cow milk fat in samples collected from farms in Khartoum, Sudan revealed $4.54 \pm 0.54 \%$. In Iran, Mirzadeh et al. (2010) found that fat content was $3.90 \pm 0.97 \%$ and in India, the average milk fat content was $3.8 \%$ (Eckles and Combs 2004). Variation was reported in the fat content of cows' milk (3.5\%-5.5\% in Sudan (Warsama et al. 2017). Also, Eckles and Combs (2004) concluded that the fat content is the most valuable constituent of milk and is considered as the food value of the milk. However, Shuiep et al. (2016) indicated that the local Sudanese cows are capable of producing significantly $(\mathrm{P} \leq 0.05)$ higher milk fat throughout their lactations.

The data in Table 1 showed the average protein content of milk samples collected from South and North Omdurman. The values in protein percentages were significantly $(\mathrm{P} \leq 0.05)$ different. The average protein content (Table 2) of milk samples collected from South Omdurman (3.59 $\pm 0.33 \%)$ was significantly $(\mathrm{P} \leq 0.05)$ higher than that collected from North Omdurman (3.47 $\pm 0.25 \%)$. Higher values were found previously by Ahmed and El Zubeir (2007) who reported that the average protein content was $3.73 \pm 0.58 \%$. Also, Landi et al. (2011) indicated that the protein of cow milk was $3.75 \pm 0.06 \%$. However lower values were reported previously in Khartoum North and Omdurman $(3.08 \pm 0.59 \%$ and $2.93 \pm 0.47 \%$, respectively) by Mohamed and El Zubeir (2007b). Mirzadeh et al. (2010) found the protein content of cow milk was $2.94 \pm 0.46$ and Bille et al. (2009) reported a value of $3.01 \pm 0.53 \%$.

The protein content of milk samples transported by cars $(3.51 \pm 0.28 \%)$ was low compared to the milk samples transported by the donkeys (3.55 $\pm 0.31 \%)$. The data in Table 3 revealed non-significant $(\mathrm{P} \geq 0.05)$ variations. Similarly, Elsheikh et al. (2015) reported that the protein content of milk obtained from pick-up trucks and venders on donkey carts was $3.59 \pm 0.19 \%$ and $3.51 \pm 0.24 \%$, respectively. Also, the result in this study was supporting Negash (2012) as he obtained $3.46 \pm 0.04 \%$ for protein content in milk sampled in Ethiopia.

The difference in the lactose means of the milk samples collected from South Omdurman $(4.69 \pm 0.36 \%)$ revealed significantly $(P \leq 0.05)$ higher values compared to that collected from North Omdurman $(4.69 \pm 0.36 \%)$ as shown in Table 1 and 2. However Bashir and El Zubeir (2013) found the average of lactose in milk from Baggara cattle in Western Sudan was $4.89 \pm 0.33 \%$. The content of milk lactose obtained from venders using cars $(4.73 \pm 0.39 \%)$ revealed lower $(\mathrm{P} \geq 0.05)$ value compared to that distributed by venders using the donkeys $(4.8 \pm 0.42 \%)$ as shown in Table 3 . The value of milk lactose content of whole milk from bovine is highly consistent; it varies from $4.5 \%$ to 5.1\% (Shuiep et al. 2016; Warsama et al. 2017). However higher level was found by Elsheikh et al. (2015) for the lactose of milk sampled from pick-up trucks $(4.88 \pm 0.23 \%)$ in comparison to venders transporting their milk via donkeys $(4.77 \pm 0.27 \%)$. Moreover, the milk sampled from the farms revealed higher lactose content $(4.35 \pm 0.08 \%)$ compared to those collected from vendors $(3.91 \pm 0.19 \%)$ as was reported by Javaid et al. (2009). Lactose has an important relation to the manufacture of the milk products, due to the fact that it is easily decomposed by bacteria (Eckles and Combs 2004).

The means of total solids content (Table 1) of milk samples collected from South and North Omdurman showed significant $(\mathrm{P} \leq 0.05)$ differences.

The average total solids content (Table 2) of milk samples collected from South Omdurman $(14.4 \% \pm 1.4 \%)$ was significantly $(\mathrm{P} \leq 0.05)$ higher than that collected from North Omdurman $(13.75 \pm 1.2 \%)$. Lower values were found by Bille et al. (2009) who found that the range of total solids was $10.64 \%$ to $13.41 \%$ and Gemechu et al. (2015) found the total solids was $12.87 \%$. However Mansour et al. (2012) found that the cow's milk sampled from the dairy farms contained $12.4 \%$ total solids. Nateghi et al. (2014) found that the total solids of milk in summer (13.31\%) was significantly higher than winter milk (12.02\%). The variations could be due to many factors including geographical location, climate conditions, breed and types of feed.

The mean of total solids content of milk transported by cars $(13.85 \% \pm 1.3 \%)$ was significantly $(\mathrm{P} \leq 0.05)$ lower compared to that obtained from the donkeys $(14.35 \% \pm 1.32 \%)$ as illustrated in Table 3 . The mean value recorded by Elsheikh et al. (2015) was $14.04 \pm 0.87 \%$ for the samples of milk transported by pick-up trucks, The high total solids content (15.2\%) was found in the milk samples from rural area of Northern Omdurman transported by donkeys while low total solids content of milk (8.2\%) was noted for the samples of milk sold by venders transporting their milk by cars in Southern Omdurman (Table 1).

The variations of the ash percentages were not significant $(P \geq 0.05)$ in the milk samples collected from both Southern $(0.67 \% \pm 0.07 \%)$ and Northern Omdurman $(0.66 \% \pm 0.09)$ as presented in Table 1 and 2. Similarly the ash content of the milk obtained from cars $(0.67 \% \pm 0.091 \%)$ compared to that of obtained from the donkeys $(0.68 \% \pm 0.061 \%)$ were insignificant $(\mathrm{P} \geq 0.05)$ (Table 3). However, the ash 
content differed significantly $(\mathrm{P}<0.05)$ from the milk samples from the cross-breed $(0.97 \%)$ and other local or exotic breeds investigated in Nigeria (Dandare et al. 2014).

The result found for milk samples transported by donkeys $(0.68 \pm 0.061 \%)$ was higher than that $0.57 \%$ found by Mustafa et al. (1991). The high ash content $(0.79 \%)$ was recorded for the milk samples from rural area of Northern Omdurman transported by donkeys while low ash content $(0.28 \%)$ was found in the milk transported by cars in Northern Omdurman (Table 1). Slightly higher ash content in the current study was found than those of Ayub et al. (2007) who recorded maximum ash content of $0.71 \%$.

The high fat, protein and lactose content shown in Table 1 were found in the milk samples collected from South Omdurman transported by donkeys. The present results showed higher values than those reported by Shuiep et al. (2016) who found fat, protein and lactose were $5.31 \pm 0.31 \%, 3.31 \pm 0.18 \%$ and $5.44 \pm 0.23 \%$, respectively. However, low fat, protein, and lactose content $(3.41 \%, 2.67 \%$ and $3.07 \%$ ) were observed in milk samples collected from North Omdurman transported by cars (Table 1). The result in Table 1 for the raw milk (fat, protein, lactose, and total solids) obtained from South Omdurman showed significantly $(\mathrm{P} \leq 0.05)$ higher values than those obtained from North Omdurman.

The means of the milk chemical constituents were affected by area, which might be due to adulteration practices by venders in North Omdurman that were more than South Omdurman (Table 4) while the ash content obtained from North and South Omdurman was insignificant $(\mathrm{P} \geq 0.05)$. The lower values of chemical constituents might be due to adulteration of milk by the addition of water (El Zubeir et al. 2008).
However, Bashir and El Zubeir (2013) attributed the variations in compositional content to the genetic variations of the animals and plane of cows' nutrition and their yield. Also, Dandare et al. (2014) pointed out that comparison of the proximate analysis of milk samples from four different breeds of cattle has shown that Holstein Friesian had less desirable traits nutritionally, which could be attributed to its adaptation to the herd management practices in Nigeria.

\section{Presence of adulterants and chemical preservatives in milk samples:}

The present result indicated that of the examined milk samples, $20(16.7 \%)$ revealed the addition of water, while 3 (2.5\%) showed boric acid and $23(19.2 \%)$ were contaminated with formalin (Table 4). However, the collected milk samples were found free from starch, hydrogen peroxide and sodium bicarbonate. The use of even minute quantities of nitrate, boric acid, salicylic acid, carbonate, bicarbonate, hydrogen peroxide and formalin as preservatives is considered by the regulatory bodies as ones of the oldest adulterant for dairy industry as they delay the spoilage of milk by improving its keeping quality (Mansour et al. 2012). Instead, for ensuring the consumers health, pasteurization of milk should be applied for extending the shelf life and quality of the dairy products (Abd Elrahman et al. 2009).

\section{Added water:}

There were 6 and 5 samples, which accounted for $20 \%$ and $16.7 \%$ of the total milk samples distributed by cars and donkeys respectively; they were positive for the addition of water (Table 4).

Table (4): Comparison of adulterants and preservatives of milk samples collected from North and South Omdurman rural area

\begin{tabular}{|c|c|c|c|c|c|c|c|c|c|c|}
\hline \multirow{3}{*}{$\begin{array}{l}\text { Venders } \\
\text { Regions } \\
\text { Adulterati }\end{array}$} & \multicolumn{4}{|c|}{ Cars } & \multicolumn{4}{|c|}{ Donkeys } & \multirow[t]{2}{*}{ Total } & \multirow[t]{3}{*}{ Percent } \\
\hline & \multicolumn{2}{|c|}{$\begin{array}{c}\text { South } \\
\text { Omdurman }\end{array}$} & \multicolumn{2}{|c|}{$\begin{array}{c}\text { North } \\
\text { Omdurman }\end{array}$} & \multicolumn{2}{|c|}{$\begin{array}{c}\text { South } \\
\text { Omdurman }\end{array}$} & \multicolumn{2}{|c|}{$\begin{array}{c}\text { North } \\
\text { Omdurman }\end{array}$} & & \\
\hline & & & & & & & & & & \\
\hline Starch & 0 & 0 & 0 & 0 & 0 & 0 & 0 & 0 & 0 & 0 \\
\hline $\mathrm{H}_{2} \mathrm{O}_{2}$ & 0 & 0 & 0 & 0 & 0 & 0 & 0 & 0 & 0 & 0 \\
\hline Formalin & 3 & $10 \%$ & 7 & $23.3 \%$ & 4 & $13.3 \%$ & 9 & $30 \%$ & 23 & $19.2 \%$ \\
\hline $\begin{array}{l}\text { Boric } \\
\text { acid }\end{array}$ & 3 & $10 \%$ & 0 & 0 & 0 & 0 & 0 & 0 & 3 & $2.5 \%$ \\
\hline $\mathrm{Na} 2 \mathrm{Co} 3$ & 0 & 0 & 0 & 0 & 0 & 0 & 0 & 0 & 0 & 0 \\
\hline $\begin{array}{l}\text { Added } \\
\text { water }\end{array}$ & 4 & $13.3 \%$ & 6 & $20 \%$ & 5 & $16.7 \%$ & 5 & $16.7 \%$ & 20 & $16.7 \%$ \\
\hline
\end{tabular}

Moreover, the same table indicated that the vendors were selling milk that was highly adulterated with water both in Northern and Southern Omdurman. Data from Egypt also showed that most of samples obtained from dairy shops $(5.1 \%$ to $32.6 \%)$ and street vendors $(4.2 \%$ to $47.9 \%$ ) were adulterated with added water and partial removal of milk fat or complaining both (Mansour et al., 2012). Moreover 97\% of the milk samples in canteens of educational institutes and 93\% in the public places in Faisalabad, Pakistan had added water (Faraz et al. 2013). Also, Barham et al. (2014) explained the high and common adulteration of the milk samples (73\%) with addition of water in Pakistan which is to increase the milk volume during 
summer season in order to satisfy the high demand. However, El Zubeir et al. (2008) reported high level and occurrence for the added water in the industrial milk in comparison with raw milk collected farm bulk milk sampled in South Africa. They added that the lower level of lactose content of the milk samples is inductive of the dilution by water because the lactose level is the least variable component of milk. Dias et al. (2016) reported that milk with added water is of major concern to the consumers because it decreases its nutritious value and addition some additives to keep the density and color normal after addition of water. Hence it is important that the producers have to supply safe and high-quality milk through implementation of quality control measures at the farm level (El Zubeir et al. 2008).

\section{Starch:}

The present data indicated that the milk sampled from rural areas in Omdurman (south and north) showed negative result for the detection of the starch (Table 4). These results disagreed with Arora et al. (2004). Unlike the present result, Ahmad (2009) found that $35.5 \%$ of the milk samples were adulterated with starch in Khartoum State, Sudan. However, Barham et al. (2014) reported the addition of starch as milk adulterant in $12 \%$ of the examined samples in Pakistan.

Fortunately, all the examined milk samples from North and South Omdurman were free from starch (Table 4). The accumulation of the high amount of undigested starch in colon resulted in diarrhea, which is dangerous especially for the diabetic patients (Rideout et al. 2014).

\section{Boric acid:}

The presence of boric acid in milk sampled from South Omdurman (Table 4) agreed with the findings of El Zubeir and El Owni (2009) who reported $77 \%$ positive milk samples for boric acid in Khartoum State. However boric acid can cause nausea and vomiting as well as diarrhea, kidney damage or cute failure of circulatory system and even death (See et al., 2010). This is regardless of the fact that the addition boric acid can keep the milk for 48 hours without noticeable change (Foley et al. 1974).

\section{Formaldehyde:}

The milk distributed by vendors in North and South Omdurman was highly adulterated with formalin (Table 4). Similarly, El Zubeir and El Owni (2009) reported the presence of formaldehyde in 5 of milk samples and the contamination was high in the sale points in comparison to the farms. Similarly, Ojha et al. (2017) found that $28 \%$ of the cow milk samples in Mathura city was positive for formalin. Formalin was also found to occur in 8 of the raw milk samples sold in Iran (Moosavy et al. 2019).

The reason is that some of the sellers preserved the milk using chemicals for increasing its keeping quality. The addition of 0.01 and $0.4 \%$ formalin to the cow' milk resulted in prolonging its storage for up to 3 days at the refrigerated temperature without changes in its appearance (Karmakar 1997). Barham et al. (2014) detected adulteration of milk by formalin (11\%) in Pakistan. However, Debnath et al. (2015) reported that formaldehyde was absent. Formalin was found to cause vomiting and diarrhea in addition to the abdominal pain. Moreover, the large dose was found to lower the body temperature in addition shallow respiration, weak irregular pulse and unconscious could also be seen and when the optic nerve is affected it leads to blindness due to its potent carcinogenesis (Gwin et al. 2009).

\section{Hydrogen peroxide $\left(\mathrm{H}_{2} \mathrm{O}_{2}\right)$ :}

The hydrogen peroxide was not found in all the milk sampled from rural areas of Southern and Northern Omdurman (Table 4). However, El Zubeir and El Owni (2009) found 1 sample was contaminated with hydrogen peroxide. Also, Mansour et al. (2012) found contamination of hydrogen peroxide in only 1 (3.3\%) milk sample collected from dairy farms and 2 (3.3\%) milk samples that obtained from dairy shops in Egypt. Debnath et al. (2015) also reported that hydrogen peroxide was present in $9.68 \%$ of the fresh milk samples studied. The adulteration of milk by hydrogen peroxide was found in $13 \%$ in Pakistan (Barham et al. 2014). However, for the farms in developing tropical countries, the treatment of milk with hydrogen peroxide was found to be effective and affordable means for extending the milk keeping quality during transporting it to the market and processing plants (Odoi et al. (2003). High keeping quality of milk was noted when adding hydrogen peroxide and that a concentration of $0.04-0.05 \%$ of $\mathrm{H}_{2} \mathrm{O}_{2}$ is appropriate for preserving the milk for about 24 hours (Saha et al. 2003).

\section{Sodium bicarbonates:}

The illustrated data (Table 4) showed that the milk examined from rural areas of Southern and Northern Omdurman revealed negative results for sodium bicarbonates. Similarly, cows and buffalo's milk samples collected from dairy farms in Egypt were found negative for both carbonate and bicarbonate (Mansour et al. 2012). However, they detected that $5 \%$ of milk samples collected from cow's milk in dairy shops and $6.7 \%$ from vendors selling the milk along the streets were contaminated with carbonate and bicarbonate. Similarly carbonates/bicarbonates were found in $27 \%, 10 \%$ and $12 \%$ samples of milk that were collected during winter, summer, and rainy seasons respectively, in India (Sanjeevani et al. 2011). Moreover Debnath et al. (2015) reported that carbonates were present in $67.74 \%$ of the fresh milk samples examined. Sodium bicarbonate was detected in $10 \%$ of the raw milk sampled from local markets in Iran (Moosavy et al. 2019). Rideout et al. (2008) reported that the higher levels of carbonates/bicarbonates in the body lead to potential disruption of the hormone's signals, 
which is responsible for regulating the development and reproduction.

The data of this study showed the presence of some adulterants (Table 4). The reasons for milk adulteration are because of the gap between the demand and supply, which is large due to intensity of the consuming population, financial reasons, physical nature of the milk (aqueous and opaque) that facilitate its adulterants (Bector et al. 1998). Moreover, perishability of the milk, encourage some unscrupulous producers and vendors to preserve and neutralize it using some illegal additive for prolonging its shelf life of milk. Most of the milk is procured and marketed by not well-organized dairies that freely added some adulterants to the milk (Molle and Leonil 2005). El Zubeir et al. (2008) concluded that milk will be dangerous for human health when it was adulterated or contaminated with hazardous materials.

\section{Conclusion}

The result obtained during this study clearly indicated that the quality of raw milk sold in the rural area at Omdurman city by vendors is low especially in North Omdurman rural area. Formalin $(19.2 \%)$, the added water (16.7\%) and boric acid (2.5\%) are the common adulterants detected in the samples of raw milk. This indicates that most of the milk vendors are practicing the adulteration of milk with some adulterants to get more money and to prolong the shelf life. Because consuming milk with poor quality due to adulteration might create health hazard to humans. Hence it is necessary to establish proper milk collecting centers to check and control the hygienic quality of milk during production and marketing process.

\section{References}

1. Abd Elrahman, S.M.A., Said Ahmed, A.M.M., El Zubeir, I.E.M., El Owni, O.A.O. \& Ahmed, M.K.A. (2009). Microbiological and physicochemical properties of raw milk used for processing pasteurized milk in Blue Nile Dairy Company (Sudan). Australian Journal of Basic and Applied Sciences, 3 (4): 3433-3437.

2. Addoma, F.E., Abdelgadir, A.E., El Nahas, A. \& El Zubeir, I.E.M. (2016). Risk factors associated with antimicrobial residues in the milk consumed in Nyala, South Darfur State, Sudan. University of Khartoum Journal of Veterinary Medicine and Animal Production, 7 (1): 22-32.

3. Ahmad, A. (2009). Milk adulteration by adding water and starch at Khartoum State. Pak. J. Nutr., 8(4): 439-440. https://doi.org/10.3923/pjn.2009.439.440

4. Ahmad, K.M.F., Hafez, R.S., Morgan, S.D. \& Awad, A.A. (2015). Detection of some chemical hazards in milk and some dairy products. African Journal of Food Science, 9(4):187-193. https://doi.org/10.5897/ajfs2014.1233

5. Ahmed, M.I.A. \& El Zubeir, I.E.M. (2007). The compositional quality of raw milk produced by some dairy farms in Khartoum State, Sudan. Research Journal of Agriculture and Biological Sciences, 3(6): 902-906.

6. AOAC, Association of Official Agricultural Chemists. (2003). Official methods of analysis, (17th edition) Washington D.C. U.S.A.

7. Arora, S., Sharma, V., Raj, D., Ram, M. \& Kishore, K., (2004). Status of milk adulteration in some states of North India. Indian J. Dairy Sci., 57(1): 65-66.

8. Ayub, M., Ahmad, Q., Abbas, M., Qazi, I. M., Khattak, I. A. \& Khattak, I. A. (2007). Composition and adulteration analysis of milk samples. Sarhad Journal of Agriculture, 23(4): 1127-1130.

9. Barham, G.S., Khaskheli, M., Soomro, A H. \& Nizamani, Z.A. (2014). Extent of extraneous water and detection of various adulterants in market milk at Mirpurkhas, Pakistan. J. Agri. Vet. Sci., 7(3): 8389. https://doi.org/10.9790/2380-07318389

10. Bashir, H.H.A. \& El Zubeir, I.E.M. (2013). Milk production and reproduction performance of Baggara cattle raised under extensive and semiextensive system in South Kordofan State. Journal of Animal Advance, 3(5):192-202. https://doi.org/10.5455/japa.20130531093133

11. Bector, B.S., Ram, M. \& Singhal, O.P. (1998). Rapid platform test for detection / determination of urea in milk. Indian Dairy Man, 50: 59-60.

12. Bille, P.G., Haradoeb, B.R. \& Shigwedha, N. (2009). Evaluation of chemical and bacteriological quality of raw milk from Neudam dairy farm in Namibia. African Journal of Food, Agriculture, Nutrition and Development, 9(7): 1511-1523. https://doi.org/10.4314/ajfand.v9i7.47682

13. Bhatti, M.Y. (2010). Formalin in milk. Consultancy report of Lahore High court. Free News alerts sums' PT to 9900.

14. Chauhan, S.L., Priyanka, K.D.M., Paul, B.R. \& Maji, C. (2019). Adulteration of milk: A Review. International Journal of Chemical Studies, 7(1): 2055-2057

15. Lahankar, S.M., Chavan, U. \& Gore, N. (2019). A thorugh review on milk adulteration, its effect on health and detection tests. World Journal of Pharmaceutical Research, 8(2): 636- 646. DOI: $10.20959 /$ wjpr 20192-14176

16. Dandare, S.U., Ezeonwumelu, I.J. \& Abubakar, M.G. (2014). Comparative analysis of nutrient composition of milk from different breeds of cows. European Journal of Applied Engineering and Scientific Research, 3(2): 33-36.

17. Debnath, A., Banerjee, S., Rai, C. \& Roy, A. (2015). Qualitative detection of adulterants in milk samples from Kolkata and its suburban areas. International Journal of Research in Applied, Natural and Social Science, 3: 81-88.

18. Dias, L.A., Peres, A.M., Veloso, A.C., Reis, F.S., VilasBoas, M. \& Machado, A.A. (2009). An electronic tongue taste evaluation, Identification of goat milk adulteration with bovine milk. Sensors and Actuators B, Chemical, 136(1): 209-217. https://doi.org/10.1016/j.snb.2008.09.025 
19. Eckles, C.H. \& Combs, W.B. (2004). Milk and Milk

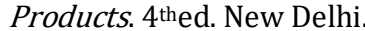

20. Elmagli. O A 0. \& El Zubeir, I.E.M. (2006). Study on the hygienic quality. Journal of Animal and Veterinary Science, 1(1): 12-17.

21. Elmagli, A.A.O., \& El Zubeir, I.E.M. (2006b). Study on the compositional quality of pasteurized milk in Khartoum State (Sudan). International Journal of Dairy Science, 1 (1): 12-20. https://doi.org/10.3923/ijds.2006.12.20

22. Elsheikh, N.A.H., Rahamtalla, S.A. \& Mohamed O.M.A. (2015). Chemical composition of raw milk produced and distributed In Khartoum State, Sudan. Asian Journal of Agriculture and Food Sciences, 3(1): 34-39.

23. El Zubeir. I E M. \& El Owni. O AO. (2009). Antimicrobial resistance of bacteria associated with raw milk contaminated by chemical preservatives. World Journal of Dairy and Food Sciences, 4(1): 65-69.

24. El Zubeir, I.E.M., Gabriechise, V. \& Johnson, Q. (2008). Comparison of chemical composition and microbial profile of raw and pasteurized milk of the Western Cape, South Africa. International Journal of Dairy Science, 3(3): 137-143. https://doi.org/10.3923/ijds.2008.137.143

25. Faraz, A., Lateef, M., Mustafa, M.I., Akthar, P. \& Yaqoob, M. (2013). Detection of adulteration, chemical composition and hygienic status of milk supplied to various canteens of educational institutes and public places in Faisalabad. Journal of Animal and Plant Science, 23: 119-124.

26. FDA. (2009). Public meeting on economically motivated adulteration. Available from, http: //www.gpo.gov/fdsys/pkg/FR-2009-04-06/pdf/E97843.pdf.

27. Foley, J., Buckley, J. \& Murphy, F.M. (1974). Commercial testing product control in the dairy industry. University Collage Cork, Ireland.

28. Gemechu, T., Beyene, F. \& Eshetu, M. (2015). Physical and chemical quality of raw cow's milk produced and marketed in Shashemene Town, southern Ethiopia. ISABB Journal of Food and Agriculture Science, 5(2): 7-13.

29. Gwin, M.C., Lienert, G. \& Kennedy, J. (2009). Formaldehyde exposure and asthma in children. $A$ systematic review. Environ. Health Perspect., 118: 313-317.

30. Haug, A., Hostmark, A.T. \& Harstad, O.M. (2007). Bovine milk in human nutrition - a review. Lipids in Health and Disease, 6: 25-41. http: //dx.doi.org/10.1186/ 1476-511X-6-25

31. Javaid, S.B., Gadahi, J.A., Khaskheli, M., Bhutto, M.B., Kumbher, S. \& Panhwar, A.H. (2009). Physical and chemical quality of market milk sold at Tandojam. Pak. Vet. J., 29 (1): 27-31.

32. Jivraj, M. \& Astha, P. (2015). Quality assessment and detection of adulteration in buffalo milk collected from different areas of Gandhinagar by physico-chemical method. International Journal of Pharm. Tech. Research, 8(4): 602-607.
33. Kamthania, M., Saxena, J., Saxena, K. \& Sharma, D.K. (2014). Methods of Detection and Remedial Measures. Int. J. Eng. Tech. Res., 1: 15-20.

34. Kandpal, S.D., Srivastava, A.K. \& Negi, K.S. (2012). Estimation of quality of raw milk (open and branded) by milk adulteration testing kit. Indian J. Community Health, 24(3): 188-192.

35. Karmakar, B. (1997). Effect of chemical preservatives on different constituents of cow milk during storage under refrigerated condition. Heiron, 26 (5-6): 89-93.

36. Kumar, R., Singh, D. K., \& Chawla, N. K. (1998). Adulteration/ contamination of milk demystified. Indian Dairyman, 50, 25-33.

37. Landi, H., Barros, L. \& Micheo, C. (2011). Evaluation of the dairy cow biotype through milk composition, nutrition and gratins management. Livestock Research for Rural Development, 23(4): Available from http: //www.lrrd.org/lrrd23/4/land23090.html.

38. Lateef, M., Faraz, A., Mustafa, M.I., Akhtar, P. \& Bashir, M. K. (2009). Detection of adulterants and chemical composition of milk supplied to canteens of various hospitals in Faisalabad city. Pakistan Journal of Nutrition, (9): 139-142.

39. Mansour, A.I.A., El-Loly, M.M. \& Ahmed, R.O. (2012). A preliminary detection of physical and chemical properties, inhibitory substances and preservatives in raw milk. Internet Journal of Food Safety, 14: 93-103.

40. Mirzadeh, K.H., Masoudi, A., Chaji, M. \& Bojarpour, M. (2010). The composition of raw milk processing by some dairy farm in Lordegan region of Iran. Journal of Animal and Veterinary Advances, 9(11): 1582-1583 https://doi.org/10.3923/javaa.2010.1582.1583

41. Mohamed N.N.I. \& El Zubeir I.E.M. (2007a). Evaluation of the hygienic quality of market milk of Khartoum State (Sudan). International Journal of Dairy Science, 2(1): 33-41. https://doi.org/10.3923/ijds.2007.33.41

42. Mohamed, N.N.I. \& El Zubier, I.E.M. (2007b). Comparison of some composition quality measurement of market milk in Khartoum State, Sudan. International Journal of Dairy Sciences, 2(1): 42-49. https://doi.org/10.3923/ijds.2007.42.49

43. Molle, D. \& Leonil, J. (2995). Quantitative determination of bovine $\kappa$-casein macro peptide in dairy products by liquid chromatography/ electrospray coupled to tandem mass spectrometry (LC-ESI/MS) and Liquid Chromatography/ Electrospray Coupled to Tandem Mass Spectrometry (LC-ESI/MS/MS). International Dairy Journal, 15(5): 419-428. https://doi.org/10.1016/j.idairyj.2004.08.013

44. Moore, J.C., Spink, J. \& Lipp, M. (2012). Development and application of a database of food ingredient fraud and economically motivated adulteration from 1980 to 2010. Journal of Food Science, 77(4):118-126. https://doi.org/10.1111/j.17503841.2012.02657.x

45. Moosavy, M.H., Kholafazad Kordasht, H., Khatibi, S.A., Sohrabi, H. (2019). Assessment of the chemical adulteration and hygienic quality of raw 
cow milk in the northwest of Iran. Quality Assurance and Safety of Crops \& Foods, 11(5): 491-498. https://doi.org/10.3920/QAS2019.1605

46. Mustafa, M.I., Bakht, B.K., Abdullah, M. \& Khan, L.A. (1991). Chemical and hygienic quality of milk supplied to canteens of various educational institutions in Faisalabad city. Pak. J. Agri. Sci., 28 (1): 9-12.

47. Negash, F., Tadesse, E. \& Woldu, T. (2012). Microbial quality and chemical composition of raw milk in the Mid-Rift Valley of Ethiopia. African Journal of Agricultural Research, 7 (29): 4167 4170. https://doi.org/10.5897/ajar12.830

48. Nateghi, L., Yousefi, M., Zamani, E., Gholamian, M. \& Mohammadzadeh, M. (2014). The effect of different seasons on the milk quality. European Journal of Experimental Biology, 4(1): 550-552.

49. Odoi, A., Siefert, L. \& Opuda-Asibo, J. (2003). Effectiveness and affordability of hydrogen peroxide in milk preservation under tropical conditions. Milchwisenschaft, 58 (1-2): 65-67.

50. Ojha, S., Pathak, V., Goswami, M., Bharti, S.K., Singh, V.P. \& Singh, T. (2017). Quality and safety assessment of cow'milk in different regions of Mathura city. Nutrition \& Food Science, 47 (3): 443-455. https://doi.org/10.1108/NFS-05-2016-0067

51. Ozer, B.H., Kirim, B. \& Atamer, M. (2000). Effect of hydrogen peroxide on the quality of raw cream. International Journal of Dairy Technology, 53(3): 83-86. https://doi.org/10.1111/j.1471-0307.2000.tb02665.x

52. Recio, I., Garcia-Risco, M.R., López-Fandiño, R., Olano, A. \& Ramos, M. (2000). Detection of rennet whey solids in UHT milk by capillary electrophoresis. International Dairy Journal, 10(5): 333-338. 6946(00)00076-5

53. Rideout, T.C., Liu, Q., Wood, P. \& Fan, M.Z. (2008). Nutrient utilization and intestinal fermentation are differentially affected by the consumption of resistant starch varieties and conventional fibers in pigs. British Journal of Nutrition, 99(5): 984-992. https://doi.org/10.1017/s0007114507853396

54. Saha, B.K., Ali, M.X., Chakraorty, M., Islams, Z. \& Hira, A.K. (2003). Study on the preservation of raw milk with hydrogen peroxide for rural dairy farmer. Pakistan J. Nut., 2(1): 39-42. https://doi.org/10.3923/pjn.2003.36.42
55. Salman, A.M. \& Hamad I.M. (2011). Enumeration and identification of coliform bacteria from raw milk in Khartoum State, Sudan. Journal of Cell and Animal Biology, 5(7):121-128.

56. Sanjeevani, B.W., Chavan, B.R. \& Menkudale, G.V. (2011). Survey on adulteration of the milk received from Government milk scheme in banded town. Journal of International Link Research Analysis, 1 (4): 32-35.

57. See, A.S., Salleh, A.B., Bakar, F.A., Yusof, N.A., Abdulamir, A.S. \& Heng, L.Y. (2010). Risk and health effect of boric acid. Am. J. Applied Sci., 7(5): 620-627. https://doi.org/10.3844/ajassp.2010.620.627

58. Shuiep, E.S., Eltaher, H.A. \& El Zubeir, I.E.M., (2016). Effect of stage of lactation and order of parity on milk composition and daily milk yield among local and crossbred cows in south Darfur state, Sudan. SUST Journal of Agricultural and Veterinary Sciences, 17(2): 86-98.

59. Singh, A., Chandra, G., Aggarwal, A. \& Kumar, P. (2012). Adulteration detection in milk. Double Helix Research, (5): 52-55.

60. Singh, P., Gandhi, N. Milk preservatives and adulterants: processing, regulatory and safety issues. Food Reviews International, 31(3), 236261. doi.org/10.1080/87559129.2014.994818

61. Spink, J. \& Moyer, D.C.S. (2011). Monitoring the authenticity of Brazilian UHT milk: A chemometric approach defining the public health threat of food fraud. J. Food Sai., 76(9): 157-163. https://doi.org/10.1111/j.1750-3841.2011.02417.x

62. Tipu, M.S., Altaf, I., Ashfaqu, M. \& Siddique, S. (2007). Monitoring of chemical adulterants and hygienic status of market milk. Handbook published by Quality Control Laboratory, Uni. Vet. Ani. Sci., Lahore, Pakistan. pp 7-39.

63. Warsama, L.M., Mustafa, N.E.M. \& El Zubeir, I.E.M. (2017). Physicochemical properties and microbial load of cow milk collected from milk supply chain during winter and summer in Khartoum State, Sudan. University of Khartoum Journal of Veterinary Medicine and Animal Production, 8 (1): 41-52.

64. Yiu, P.H., See, J., Rajan, A. \& Bong, C.F.J. (2008).

Boric acid levels in fresh noodles and fish ball. Am. J. Agril. Biol. Sci., 3(2): 476-481. https://doi.org/10.3844/ajabssp.2008.476.481 